\title{
Şehir Hastanelerine İlişkin Haberlerin Gazetelerde Yansıması
}

\author{
The Reflection of News About City Hospitals in Newspapers \\ Gülcan ŞANTAŞ* \\ Fatih $\operatorname{S} A N T A S^{* * *}$
}

$\ddot{O} Z$

Bu çalışma, şehir hastanelerinin medyada nasıl ele alındığının belirlenmesi amacıla gerçekleştirilmiştir. Çalışma tanımlayıcı niteliktedir. Çalışma 01 Aralık 2017- 01 Aralık 2018 döneminde Türkiye’de tirajı en yüksek ve web sitelerinden arşiv sayılarına ulaşılabilen üç gazete üzerinden gerçekleştirilmiştir. Çalışmada ulaşılan haberler içerik analizine tabi tutulmuştur. Araştırma kapsamında yer alan üç gazetede son bir yıl içerisinde şehir hastanesi ile ilgili 221 haberin yer aldı ̆̆ belirlenmiştir. En fazla haber, 108 ile Sabah gazetesinde yer almıştır. Şehir hastaneleri ile ilgili haberlerde en fazla gündeme gelen konu, hastanenin yapımının devam etmesidir. İkinci sırada hastanelerin yatak sayıs ve üçüncü sırada ise hastanelerin 5 yıldızlı otel şeklinde ifade edilmesi bulunmaktadır. Hastaneler halen açılma ve yeni kullanım sürecinde olup, yapılma aşamasında belirlenen hedeflere ulaşılıp ulaşılamayacağının zaman içinde belli olacağ söylenebilir.

\section{ANAHTAR KELIMELER}

Şehir Hastaneleri, Gazete, İçerik Analizi.

\begin{abstract}
This study was carried out to determine how city hospitals are handled in the media. The study was descriptive. The study was conducted on three newspapers with the highest circulation, that archives can be accessed from the website of circulation in Turkey in the period of December 1, 2017-December 1, 2018. The content of the study was subjected to content analysis. It was determined that there were 221 news about the city hospital in three newspapers in the scope of the research. The most recent news was published in the newspaper Sabah with 108. The most mentioned subject in the news was "continued construction" about the city hospitals. The number of hospital beds was in the second place, and "the emphasis of 5-star hotel" was in the third place. Hospitals are still in the process of opening and new use; it can be said that the targets determined during the construction phase will be certain in time.
\end{abstract}

\section{KEYWORDS}

City Hospitals, Newspaper, Content Analysis.

\begin{tabular}{|c|c|c|}
\hline \multicolumn{2}{|c|}{ Makale Geliş Tarihi / Submission Date } & \multicolumn{1}{c|}{$\begin{array}{c}\text { Makale Kabul Tarihi / Date of Acceptance } \\
\text { O1.03.2019 }\end{array}$} \\
\hline \multirow{4}{*}{ Atıf } & $\begin{array}{l}\text { Santaş, G., Santaş, F. (2019). Şehir Hastanelerine İlişkin Haberlerin Gazetelerde Yansıması. Selçuk Üniversitesi } \\
\text { Sosyal Bilimler Meslek Yüksekokulu Dergisi, 22 (1), 104-111 }\end{array}$ \\
\hline
\end{tabular}

\footnotetext{
* Dr. Öğr. Üyesi, Yozgat Bozok Üniversitesi İktisadi ve İdari Bilimler Fakültesi Sağlık Yönetimi Bölümü, gulcan.santas@bozok.edu.tr, ORCID: 0000-0002-0488-9375

${ }_{* * *}$ Dr. Öğr. Üyesi, Yozgat Bozok Üniversitesi İktisadi ve İdari Bilimler Fakültesi Sağllk Yönetimi Bölümü, fatih.santas@bozok.edu.tr, ORCID: 0000-0002-0595-4183
} 


\section{GİRIŞ}

Şehir hastaneleri, Kamu Özel İşbirliği (Yap - Kirala - Devret) modeliyle ve 21/02/2013 tarih ve 6428 sayılı "Sağlık Bakanlığınca Kamu Özel İş Birliği Modeli İle Tesis Yaptırılması, Yenilenmesi ve Hizmet Alınması İle Bazı Kanun ve Kanun Hükmünde Kararnamelerde Değişiklik Yapılması Hakkında Kanun” kapsamında ortaya çıkmış bir yatırım finansman modelidir. Bu modelle birlikte kamu hizmetlerinin finansmanında ve sunumunda etkinlik ve verimliliğin sağlanması hedeflenmektedir (Sağlık Bakanlığı, 2018a).

$\mathrm{Bu}$ çalışmada, şehir hastanelerine ilişkin haberlerin gazetelerde yansımasının ele alınması amaçlanmaktadır. Gazete haberleri toplumu bilgilendirme, bilinçlendirme ve yönlendirme anlamında önemli kitle haberleşme araçlarından biridir (Zeyrek, 1992: 59). Enformatik medyanın sağlikta kullanımı yoluyla enformasyon gazetecilere, sağlık çalışanlarına, topluma ve benzeri hedef kitleye iletilebilmektedir (Çınarlı, 2008: 105). Günlük gazetelerde yer alan haberlerin birey tarafindan sorgulanmadan geçerli bilgi olarak algılanması olasılığ bulunmaktadır. Bu sebeple, gazete haberlerinin toplumu bilgilendirmede önemli bir kaynak olduğu ileri sürülmektedir (Özşaker ve diğerleri, 2007: 81; Ertem ve diğerleri, 2009: 71). Şehir hastaneleri, Türkiye'de son dönemde sağlık politikasında önemli bir gündem maddesi olması sebebiyle, medyada yer verilen konu başlıklarından biridir. Bu çalışmada, gazete haber başlıklarında şehir hastanelerinin nasıl ele alındığının ortaya konulmasıyla alanyazına katkı sağlanması hedeflenmektedir.

\section{1.ŞEHIR HASTANELERI}

Şehir hastaneleri kamu hastaneleri olup, maliyetin yüksek olması sebebiyle ertelenen sağlık projelerinin hayata geçirilmesi amacıyla gündeme gelmiştir (Sağlık Bakanlığı, 2018a). Bu hastaneler ile kamu özel işbirliği modelinden faydalanarak, kamu hizmetlerinin finansmanında ve sunumunda etkinlik ve verimliliğin sağlanması hedeflenmektedir (Organ ve Tekin, 2017: 256).

Şehir hastanelerinin işleyişinde özel sektör, projelerin inşaatı ve bazı hizmet kollarında işletme sürecini yürütmektedir. Hastanenin genel işletmesi, sağlık hizmetleri ve idari hizmetler Sağlık Bakanlığı mevzuatına göre yürütülmektedir. Projeler yap-kirala-devret modeliyle yürütüldüğü için, kira dönemi sonunda (25 yıl) proje kamuya devredilmektedir. Bu süreçlerin takibi ve uygulanma süreci Sağlık Bakanlığı'nın "Şehir Hastaneleri ve Koordinasyon Dairesi Başkanlığı" tarafından koordine edilmektedir (Sağlık Bakanlığı, 2018a).

Sağlık hizmetlerinde şehir hastanesi uygulamasına geçilmesiyle birlikte, kamu özel işbirliği uygulamasından faydalanılacak alanlar şu şekildedir (Karasu, 2011: 224):

- Sağlık tesislerinin belirli bir kira bedeli karşılığında yaptırılması

- Sağlık tesislerinin bakım, onarım ve yenilenme işlerinin yaptırılması

- T1bbi destek hizmetlerinin sunumu

- Tıbbi hizmetler dışındaki hizmetlerin (temizlik, yemekhane, çamaşırhane vb.) sunumu

- Tibbi hizmetler dışındaki alanların işletilmesi

- Sağlık tesislerindeki tüm tıbbi cihazlar ve eşyaların sağlanması.

Şehir hastaneleri, "Entegre Sağlık Kampüsleri” olarak da ifade edilmektedir ve Türkiye'de sağlık alanında kamu özel işbirliğine yönelik adımlar başlatılmıştır (Acartürk ve Keskin, 2012: 45). 2018 yılına kadar 8 şehirde (Yozgat, Isparta, Mersin, Adana, Kayseri, Elazı̆̆, Eskişehir ve Manisa) şehir hastanesi hizmete açılmıştır. 2018 yılı sonunda Ankara Bilkent Entegre Sağlık Kampüsü’nün hastaların kullanımına açılması planlanmaktadır. 2019-2020 yıllarında açılması planlanan ve şuan inşaatı devam eden 11 hastane, ihale süreci devam eden 8 hastane, ihale hazırlık çalışmaları devam eden iki hastane ve planlama aşamasında bir hastane bulunmaktadır (Sağlık Bakanlığı, 2018b). Şehir hastanelerinin mevcut durumu Tablo 1'de görülmektedir. 
Tablo 1. Şehir Hastanelerinin Mevcut Durumu

\begin{tabular}{|c|c|c|c|}
\hline Proje Aşaması & iller & Yatak Sayısı & $\begin{array}{c}\text { Projenin Tamamlanma } \\
\text { Süresi }\end{array}$ \\
\hline \multirow{8}{*}{ Yapımı Tamamlananlar } & Yozgat Şehir Hastanesi & 475 & Açıldı \\
\hline & Isparta Şehir Hastanesi & 755 & Açıldı \\
\hline & Mersin Şehir Hastanesi & 1.294 & Açıldı \\
\hline & Adana Şehir Hastanesi & 1.550 & Açıldı \\
\hline & Kayseri Şehir Hastanesi & 1.607 & Açıldı \\
\hline & Elazığ Şehir Hastanesi & 1.038 & Açıldı \\
\hline & Eskişehir Şehir Hastanesi & 1.081 & Açıldı \\
\hline & Manisa Eğitim ve Araştırma Hastanesi & 558 & Açıldı \\
\hline \multirow{13}{*}{ İnşaatı Devam Edenler } & Ankara Bilkent Entegre Sağlık Kampüsü & 3.704 & 2018 \\
\hline & Ankara Etlik Entegre Sağıık Kampüsü & 3.577 & 2019 \\
\hline & Bursa Entegre Sağlık Kampüsü & 1.355 & 2019 \\
\hline & Tekirdağ Devlet Hastanesi & 480 & 2020 \\
\hline & Konya Karatay Entegre Sağlık Kampüsü & 838 & 2020 \\
\hline & Kütahya Şehir Hastanesi & 600 & 2020 \\
\hline & Kocaeli Entegre Sağlık Kampüsü & 1.180 & 2020 \\
\hline & Gaziantep Entegre Sağlık Kampüsü & 1.875 & 2020 \\
\hline & İzmir Bayraklı Entegre Sağlık Kampüsü & 2.060 & 2020 \\
\hline & Şanlıurfa Şehir Hastanesi & 1.700 & 2020 \\
\hline & İstanbul İkitelli Entegre Sağlık Kampüsü & 2.682 & 2020 \\
\hline & FTR, Psikiyatri ve YGAP Hastaneleri & 2.400 & 2020 \\
\hline & TітCK Kampüsü & - & - \\
\hline \multirow{8}{*}{$\begin{array}{l}\text { İhale Süreci } \\
\text { Devam Edenler }\end{array}$} & Denizli Şehir Hastanesi & 1.000 & - \\
\hline & Samsun Şehir Hastanesi & 900 & - \\
\hline & Ordu Şehir Hastanesi & 900 & - \\
\hline & Trabzon Şehir Hastanesi & 900 & - \\
\hline & Aydın Şehir Hastanesi & 950 & - \\
\hline & Diyarbakır Kayapınar Şehir Hastanesi & 750 & - \\
\hline & Antalya Şehir Hastanesi & 1.000 & - \\
\hline & İstanbul Sancaktepe Sağlık Kampüsü & 4.200 & - \\
\hline \multirow{2}{*}{$\begin{array}{l}\text { Ihale Hazırlık Çalışmaları } \\
\text { Devam Edenler }\end{array}$} & Sakarya Şehir Hastanesi & 1.000 & - \\
\hline & Rize Şehir Hastanesi & 800 & - \\
\hline Planlama Aşamasındakiler & İzmir Yenişehir (Tınaztepe) Şehir Hastanesi & 1.200 & - \\
\hline
\end{tabular}

\section{2.ŞEHİR HASTANELERİNE YÖNELİK OLUMLU GÖRÜŞLER}

Sağlık alanında 20 yıllık geçmişi bulunan kamu özel işbirliği modeli, kamuya büyük yatırımlar yapabilmesi için özel finansman sağlamaktadır. Özel sektörden teknoloji, bilgi ve beceri sağlaması sebebiyle, kamu tarafından daha güvenilir bulunan bir yatırım modelidir. Bu model sayesinde sağlık yatırımları yaparken, sermayeyi riske atmadan geri dönüşü büyük ölçüde güvence altına alınmış bir yatırıma girilmektedir (Karasu, 2011: 220). Bir başka ifadeyle, özel sektörün yapısal üstünlüklerinden yararlanılan bu modelde yatırımlar daha kısa zamanda ve belirli bir bilançoyla gerçekleştirilebilmektedir (Karahanoğulları, 2012: 122).

Şehir hastaneleri modeliyle ortaya çıkabilecek potansiyel riskler özel sektörle paylaşılabilmektedir ve uzmanlığa dayalı bir altyapı oluşturulduğu için şehir hastaneleri avantaj sağlayabilmektedir. Ayrıca, sağlık kuruluşlarının inşaat ve yapım süreçleri de kısa sürede tamamlanarak kamunun yatırım yükü yıllara yayılabilmektedir. Yapılması planlanan şehir hastanelerinin sağlık sektöründeki maliyetleri azaltabileceği, bu hastanelerde kaliteli ve etkin bir sağlık hizmeti sunumu yapılabileceği ileri sürülmektedir (Kerman ve diğerleri, 2012: 21).

Şehir hastaneleri, sağlık yatırımlarının yenilenmesi ve modernize edilmesi noktasında önemli bulunan yatırımlar arasındadır (Sağlık Bakanlığı, 2012). Daha önceki dönemlerde çok sayıda hastanın bir arada yattığı ve kargaşanın mevcut olduğu hastane odalarından "beş yıldızlı otel konforuna" ve "dev sağlık kampüslerine" geçilmesi, daha kaliteli ve daha etkin sağlik hizmeti sunumunu hedeflemektedir. Şehir hastaneleriyle birlikte 
Türkiye'de hastane yatak sayılarının arttığı, sağlık turizminde gelişmeler olduğu ve kamu hastanelerinde sağlık turizmi hizmetlerinin kalitesinin artırıldığı ifade edilmektedir (Sadeghi ve diğerleri, 2016: 1403).

Geniş bir alanda kurulması ve birçok hizmet sunması planlanan şehir hastanelerinin bir "yaşam merkezi" olduğu belirtilmektedir (Öner, 2010). Şehir hastanesi tanıtımları yapılırken sağlık hizmetlerinin sunumu yanında sosyal yaşam alanları, oteller, peyzaj alanları ve sağlık tüketicilerinin alışveriş yapabileceği merkezlerin varlığı dile getirilmektedir. Sağlık hizmeti almak için entegre sağlık kampüslerini ziyaret eden hastalar ve hasta yakınlarının şehir hastanelerinin sunduğu bu yaşam merkezi imkânlarından faydalanabilmesi tasarlanmaktadır.

Şehir hastanelerinin sunduğu bir diğer avantaj, kurulduğu şehirler için önemli bir istihdam alanı oluşturmasıdır. Yozgat, Mersin, Isparta gibi illerde kurulan şehir hastaneleri için hekim, hemşire, ebe gibi sağl1k personelinin yanı sıra temizlik personeli, güvenlik gibi diğer hizmet alanlarında da personel istihdam etmesi sebebiyle şehirlerin gelişmesine katkı sağlayabileceği ve bu şehirlerde yaşayan vatandaşların başka şehirlere iş bulmak amacıyla göç etmesini önleyebileceği düşünülmektedir. Bu yönüyle, gelişmekte olan şehirlerin kalkınmasına hizmet edebilmektedir.

Uluslararası bir çalışmada, kamu özel işbirliğinin sağlık sektöründe sağladığı faydalar şu şekilde özetlenmektedir (Sadeghi ve diğerleri, 2016: 1403):

- Hastanelerin inşası ve işletilmesini kolaylaştırmak

- İnsanların sağlık hizmetlerine erişimini sağlamak

- Hastane ve birinci basamak sağlık hizmetleri entegrasyonu

- Maliyetleri artırmadan yüksek kaliteli sağlik hizmetlerine erişim

- Ayakta tedavi hizmetleri ve ameliyatları için bekleme süresinde azalma

- Parasal değer yaratma, hastane hizmetlerinde zaman, bütçe, inisiyatif ve yenilik hizmetleri sunmak

- Kapsanan nüfus için tıbbi ve tıbbi olmayan hizmetler dâhil olmak üzere eksiksiz bir hizmet paketi oluşturulması

- Finansal, operasyonel ve yasal risklerden korunma

- Hastane ekipmanlarının yenilenmesi

- Hastane performans göstergelerinin iyileştirilmesi

- Hastaları başka merkezlere sevk etmenin gerekmemesi

Türkiye'de bir şehir hastanesinde gerçekleştirilen memnuniyet araştırmasında, hastaneden hizmet alan hastalara genel memnuniyet durumlarını değerlendirmeye yönelik sorular sorulmuştur. Çalışma sonucunda hastalar şehir hastanesinden memnun olduklarını ifade etmiştir. Hastalar, hastaneyi yeni, temiz, rahat, kullanılan araç gereçleri modern, çalışan personelin yaklaşımını ve personel yönlendirmesini iyi olarak değerlendirmişlerdir (Gökkaya ve diğerleri, 2018: 145). Bir diğer çalışmada da, şehir hastanesindeki sunulan hizmetten memnuniyet değerlendirilmiş ve hastaların genel olarak memnun oldukları belirlenmiştir (Çınar ve diğerleri, 2017: 299).

\section{3.ŞEHIR HASTANELERINE YÖNELIKK ELEŞTIRIILER}

Şehir hastanelerinin sağlık hizmetleri sunumunda sağladığı avantajlar yanında, birçok konuda eleştirildiği görülmektedir. Bu eleştiriler, şehir hastanelerinin yeni yeni açılmaya başlanmasının oluşturduğu belirsizlikler ve şehir hastanelerin politik ve yapısal zeminini oluşturan politika belirleyicilere yöneliktir.

Sağlık kurumlarında kamu özel işbirliğinin geleneksel hizmet modeliyle karşılaştırılması son derece tartışmalıdır. Ancak temelde maliyet, kalite, esneklik ve karmaşıklık olmak üzere bazı temel sorunları olduğu belirtilmektedir. Herhangi bir satın alma uygulamasında, sorunlar genellikle maliyet, zaman ve kalite sebebiyle ortaya çıabilmektedir. Devlet tek ödeyicidir. Yasal, finansal ve diğer teknik tavsiyelere olan ihtiyaç, inşaat ve yapım riskleri yüksek maliyetli olabilmektedir. Özel sektörle ortaklık kurulması durumunda ucuz bileşenlerin kullanımı, sürekli ortaya çıkan bakım maliyetleri, kötü drenaj ve sıhhi tesisat, kötü havalandırma ve hava filtrasyonu gibi kalite sorunlarıyla karşılaşılma riski bulunmaktadır. Ayrıca, bu ortaklıklar yıllara yayıldığı ve yükssek maliyet ürettiği için sağlık kuruluşlarının değişen çevre koşullarına esnek bir şekilde adapte olabilmesi de daha zor olabilmektedir (McKee ve diğerleri, 2006: 891).

Şehir hastanelerine yönelik eleştirilerden bir diğeri, daha kısa zamanda ve belirli bir bilançoyla sağlık yatırımlarına olanak tanımasında özel sektörün rolü ile ilgili olmaktadır. Kamunun özel sektörle ortaklık kurarak oluşturulan hizmet sunum modelinin geleneksel kamu hizmet üretim modeline göre üstünlüğünün olmadığı ileri sürülmektedir. Üstünlük yerine birçok konuda yeni riskler ortaya çıkardığ 1 belirtilmektedir. Sağl1k sektöründe kamu özel işbirliğinin "piyasada tekelci bir alan" ortaya çıkarabileceği ileri sürülmektedir (Karahanoğulları, 2012: 119-122). 
Şehir hastaneleri ile birinci basamak sağlık hizmetlerinin ilişkisinin değerlendirildiği bir çalışmada, şehir hastanelerinin doğasının "kâr hedeflemeye" yönelik olduğu ileri sürülmektedir. Şehir hastane tanıtımlarında bu hastanelerin yatırım maliyetlerinin karşılanıp kâra geçmeleri için belli bir doluluk oranına ihtiyaç duydukları sıkça vurgulanmaktadır. Dolayısıyla, hastane için verilen hizmetin kârlılığına ve hasta ve tıbbi işlem sayısının yüksek olması gerektiğine dikkat çekilmektedir. Ancak sunulan hizmetler sağlık hizmetleri olması sebebiyle, yüksek teknolojik donanıma sahip bu hastanelere başvuran hasta sayısının çok olması istenilen bir durum değildir. Aynı zamanda aile sağlık merkezleri, aile hekimliği ve birinci basamak sağlik hizmetlerini geliştirmeye yönelik politikalar da geliştirilmeye çalışılmaktadır. Birinci basamak sağlık hizmetleri etkin bir şekilde işleyen sağlık sistemlerinde, hastaların daha büyük hastanelere gitmek yerine birinci basamakta sağl1k hizmeti alması, hasta ve sağlık sistemi maliyetlerini azaltabilecektir. Bir yandan aile hekimliği sisteminin etkinliğini artırmaya çalışan bir yandan da şehir hastanelerine hastaları yönlendiren bir sağl1k sisteminin "bir paradoks oluşturduğu” ileri sürülmektedir (Cerrahoğlu, 2016: 81-82).

Şehir hastanelerine yönelik sağlık yöneticilerinin görüşlerinin incelendiği bir çalışmada, sağlık yöneticileri kamu özel işbirliği uygulamalarında kamunun rolünün daha fazla olması gerektiğini ifade etmişlerdir. Çalışma yazarlarına göre, özel sektörün şehir hastanelerindeki rolü ilerleyen zamanlarda özelleştirmeyi beraberinde getirebilecektir. Ayrıca sözleşme sürelerinin uzun olması ve belirsizlikler içermesi ve kamunun bu durumda çeşitli risklerle karşılaşabilmesi, şehir hastanelerine yönelik diğer bir kaygıyı oluşturmaktadır. Ayrıca, tıbbi hizmetlerin kamu tarafından ve destek hizmetlerin özel sektör tarafindan sunulmasının yönetimde iletişim sorunlarını meydana getirebileceği ifade edilmektedir (Ünal ve Köse Ünal, 2017: 56).

Bir şehir hastanesinde gerçekleştirilen memnuniyet araştırmasında, hastaların şehir hastanesinde memnun olmadıkları konular şu şekildedir: Şehir hastanesine ulaşımda karşılaşılan sorunlar, tıbbi sekreterlerin bulunmayışı, sıra bekleme, telefonun çekmemesi, işlemlerin yavaş olması, asansörün ve tekerlekli sandalyelerin azlığı, hastane içinde yaşanan ulaşım ve otopark sorunları (Gökkaya ve diğerleri, 2018: 146). Şehir hastanesinde hizmet memnuniyetine yönelik bir diğer çalışmada da, katılımcıların hasta sıra bekleme süreleri ve hastalarla ilgilenilmesi konusunda memnuniyet düzeylerinin düşük seviyede olduğu tespit edilmiştir (Çınar ve diğerleri, 2017: 229).

\section{ARAŞTIRMANIN YÖNTEMI}

Bu çalışma, Türkiye Sağlık Sisteminin dönüşümünde önemli yeri olan ve yüksek bütçeler ile yapılan şehir hastanelerinin medyada nasıl ele alındığının belirlenmesi amacıyla gerçekleştirilmiştir. Çalışma ile sağlik sisteminin en güncel konuları arasında yer alan şehir hastaneleri konusu incelenerek alanyazına katkı sağlanması amaçlanmıştır.

Çalışma tanımlayıcı niteliktedir. Çalışma, 01 Aralık 2017- 01 Aralık 2018 döneminde Türkiye'de tirajı en yüksek ve web sitelerinden arşiv sayılarına ulaşılabilen üç gazete (Sabah, Hürriyet, Milliyet) üzerinden gerçekleştirilmiştir. Veriler, gazetelerin web sitelerine şehir hastaneleri, şehir hastanesi, "şehir hastaneleri", "şehir hastanesi" kelimeleri girilerek elde edilmiştir. Çalışma kapsamında 302 haber başlığına ulaşılmış olup, 56 haber mükerrer olma, 25 haber ise konu ile ilgili olmaması nedeniyle elenmiş ve çalışma 221 haber başlığ 1 üzerinden gerçekleştirilmiştir. Çalışmada ulaşılan haberler içerik analizine tabi tutulmuştur.

\section{ARAŞTIRMANIN BULGULARI}

Tablo 2'de şehir hastanelerine ilişkin haber sayılarının dağılımı verilmektedir. Araştırma kapsamında yer alan üç gazetede son bir yıl içerisinde şehir hastanesi ile ilgili 221 haberin yer aldığı belirlenmiştir. En fazla haber, 108 ile Sabah gazetesinde yer almıştır.

Tablo 2. Gazetelerde Şehir Hastanelerine İlişkin Haberlerin Sayısı

\begin{tabular}{|l|c|}
\hline Gazete & Haber Sayısı \\
\hline Sabah & 108 \\
\hline Milliyet & 76 \\
\hline Hürriyet & 37 \\
\hline Toplam & $\mathbf{2 2 1}$ \\
\hline
\end{tabular}

Tablo 3’te gazete haberlerinin içerik analizine göre dağılımı verilmektedir. Şehir hastaneleri ile ilgili haberlerde en fazla gündeme gelen konu yapımının devam etmesidir. İkinci sırada hastanelerin yatak sayısı ve üçüncü sırada ise hastanelerin 5 yıldızlı otel şeklinde ifade edilmesi bulunmaktadır. Hastanelerin maliyetinin yüksekliği ve son teknoloji olmasının ise son sıralarda yer aldığı belirlenmiştir. 
Tablo 3. Şehir Hastanelerine İliş̧kin Haberlerin İçeriklerine Göre Dağılımı

\begin{tabular}{|l|c|}
\hline Konu & Sayı \\
\hline Yapımına devam edilmesi & 34 \\
\hline Yatak sayısı & 27 \\
\hline 5 yıldızlı otel & 26 \\
\hline Hizmet kalitesi & 24 \\
\hline Dev hastane & 22 \\
\hline Hizmet sayıları & 18 \\
\hline Hastane tanıtımı & 17 \\
\hline Sağlık turizmi & 10 \\
\hline Hastanelere ulaşım & 9 \\
\hline Diğer kurum ve kuruluşlara garanti verilmesi & 8 \\
\hline Yeni hastane yapılmasının planlanması & 8 \\
\hline Lüks & 6 \\
\hline Başka ülkelerce örnek alınması & 4 \\
\hline Üniversite ile şehir hastanesi işbirliği & 3 \\
\hline Yüksek maliyet & 3 \\
\hline Son teknoloji & 2 \\
\hline
\end{tabular}

\section{TARTIŞMA VE SONUÇ}

$\mathrm{Bu}$ çalışmada şehir hastanelerinin medyada nasıl ele alındığının belirlenmesi amaçlanmaktadır. Çalışma tanımlayıcı nitelikte olup; ulaşılan haberler içerik analizine tabi tutulmuştur.

Üç gazetede son bir y1l içerisinde yer alan toplam 221 haber kapsamında en fazla gündeme gelen haber, şehir hastanelerinin yapımının devam etmesidir. 2018 yılına kadar Yozgat, Isparta, Mersin, Adana, Kayseri, Elazığ, Eskişehir ve Manisa'da planlanan şehir hastaneleri hizmete açılmıştır ve vatandaşlar bu hastanelerden sağlık hizmeti almaya başlamıştır. 2018 yılı sonunda da Ankara Bilkent Entegre Sağlık Kampüsü'nün hastaların kullanımına açılması planlanmaktadır. 2019 Yılı Bütçe Sunumu TBMM Plan Bütçe Komisyonu'nun raporuna göre hâlihazırda inşaat süreci devam eden 11 hastane bulunmaktadır ve hastane inşaatlarının büyük ölçüde yapımının tamamlandığı belirtilmektedir. Bu hastanelerin 2019 ve 2020 yıllarında açılması planlanmaktadır (Sağlık Bakanlığı, 2018b). Dolayısıyla, şehir hastanelerine ilişkin "yapımının ve inşaatının devam etmesine" ilişkin haberlerin daha çok olması anlaşılabilmektedir. Yapılan bu haberlerin bu şehirlerde yaşayan vatandaşların bilgi sahibi olması ve farkındalıklarının artmasına katkı sağladığı düşünülebilir. Ayrıca, raporda ihale süreci devam eden 8 hastane, ihale hazırlık çalışmaları devam eden iki hastane ve planlama aşamasında bir hastane olduğu belirtilmektedir. Şehir hastanelerine yönelik bu tür bilgilendirmeler yapılmasının, daha şeffaf sağlık politikalarının belirlenebilmesine katkı sağlayabileceği düşünülmektedir. Bir şehir hastanesinin kuruluş yerinin belirlenmesi ve hizmete açıllş takviminin belirlenmesi sadece o hastaneyi ve çalışanlarını etkilememektedir. Hastanenin kurulduğu çevrede konumlanması planlanan eczane ve medikal cihaz ve tıbbi malzemelerin satıldığı işletmelerin planlanması için de önemli olmaktadır.

Gazete haberleri kapsamında şehir hastanelerine yönelik ikinci olarak en fazla vurgusu yapılan konu, hastanelerin yatak sayısıdır. Yapımı tamamlanan ve hizmete açılan şehir hastaneleri Yozgat (475 yataklı), Isparta (755 yatakl1), Mersin (1.294 yatakl1), Adana (1.550 yatakl1), Kayseri (1.607 yatakl1), Elazığ (1.038 yataklı), Eskişehir (1.081 yataklı) ve Manisa (558 yataklı)'dır. Bu hastanelerin yatak sayılarına bakıldığında, kurulan şehirler için önemli sağlık yatırımlarının yapıldığı söylenebilir. Bütüncül olarak düşünüldüğünde, hastane sadece yatak sayılarından oluşmayıp, bu yatak sayılarına paralel olarak hekim ve diğer sağlık çalışanlarının istihdamı, tıbbi donanımın niteliği, son teknolojilerin varlığı da söz konusudur. İnşaat süreci devam eden şehir hastaneleri arasında en çok tartışma konusu olan Ankara Bilkent Entegre Sağlık Kampüsü (3.704 yataklı) ve Ankara Etlik Entegre Sağlık Kampüsü (3.577 yataklı) yatak sayılarıdır. Örneğin Ankara Bilkent Entegre Sağlık Kampüsü, genel hastane, ana hastane, kalp damar, nöroloji ve ortopedi, çocuk, kadın doğum, onkoloji, fizik tedavi ve rehabilitasyon ve yüksek güvenlikli adli psikiyatri olmak üzere 9 hastaneyi kapsayacak şekilde yapılmaktadır. Bu sağlık kampüsünde görev yapacak sağlık çalışanlarının ve tıbbi ve destek hizmetlerin yönetimine ilişkin ortaya çıkabilecek potansiyel zorluklar konusu sıklıkla tartışılmaktadır. Yatak sayısının çokluğu, yönetsel zorlukları da beraberinde getirebilmektedir. Dolayısıyla, özel sektör ile kamunun hizmet sunum sürecinde kuracağı işbirliğinin sınırları net bir şekilde belirlenmiş bir yönetim yapısını gerektirmektedir. Böylesi büyük bir alanda ve hizmet sahasında kurgulanmış sağlık kampüslerinde hizmetlerin 
ölçümünün ve değerlendirmesinin yapıldığı bir kalite yönetim sistemine ihtiyaç duyulmaktadır. Şehir hastanelerini inşa eden yüklenici firmaların hastane planlaması ve inşaatı konusundaki bilgi düzeylerine yönelik belirsizlikler söz konusudur. Yatak sayısının nicelikselliğinin ötesinde niteliğinin ve yönetilebilirliğinin ön planda tutulması gereken bir yönetim yapısıyla mümkün olacağı düşünülmektedir.

Araştırma kapsamında hastanelerin beş yıldızlı otel hizmetlerine sahip olduğu haberi ise, üçüncü sırada en fazla dikkat çeken haber başlığı olmaktadır. Bu hastanelerde "beş yıldızlı otel hizmetleri" sunulduğu vurgusunun, Türkiye'de sağlı politika belirleyicilerinin önemle üzerinde durduğu sağlık turizmine katk1 sağlaması bakımından önemli olduğu düşünülmektedir. Daha önceki dönemlerde çok sayıda hastanın enfeksiyon kapma riskine rağmen bir arada tedavi gördüğü, hijyen koşullarının ve havalandırma koşullarının yetersiz olduğu, refakatçilerin ve hasta bakıcıların zor koşullarda hastasıyla ilgilenebildiği eski dönem sağlık kuruluşlarından "beş yıldızlı otel konforu" sunan hastanelere geçiş, hastalar ve hasta yakınları tarafından genellikle olumlu olarak değerlendirilmektedir. Bu hastanelerde tıbbi hizmetler dışındaki hizmetler (temizlik, yemekhane, çamaşırhane vb.), genellikle alanında uzman özel sektör işletmeleri aracılığıyla sunulmaktadır. $\mathrm{Bu}$ anlamda, bu tür hizmetlerin olumlu yansımalarını gündeme getiren haberlere sıkça yer verilmesi anlaşılabilmektedir. Şehir hastanelerine yönelik yapılan ampirik çalışmalar da sunulan hizmetlerden memnun olunduğunu göstermektedir. Bu hastanelerde hizmet alan hastalar, hastaneyi yeni, temiz, rahat, kullanılan araç gereçleri modern ve çalışan personelin yaklaşımını ve personel yönlendirmesini iyi olarak değerlendirmektedirler (Gökkaya ve diğerleri, 2018: 145). Bir diğer çalışmada da, şehir hastanesindeki sunulan hizmetten yararlanan hastaların genel olarak memnun oldukları belirlenmiştir (Çınar ve diğerleri, 2017: 299).

Çalışmada son olarak, şehir hastanelerinin maliyetinin yüksekliği ve son teknoloji olması, son sıralarda yer alan haber başlıkları arasındadır. Şehir hastaneleri yeni yeni açılmaya başladığ çok yeni olduğu için, hizmetlerin maliyetlerini değerlendirme noktasında haberlerin daha az olması anlaş1labilmektedir. Vatandaşların cepten ödeyecekleri maliyetlerin ve son teknoloji kompleks hizmetlerden yararlanmanın getirdiği maliyetlerin gelecek dönemlerde daha fazla tartış1labileceği düşünülmektedir. Ancak bu hastanelerin sunduğu özellikli hizmetlerden faydalanabilmek için vatandaşın katlanacağı maliyetlerin artacağı konusunda endişeler söz konusudur. Örneğin daha önce yakın mesafelerde konumlanmış hastanelerden faydalanan hasta için ulaşım hem maddi hem de manevi maliyetler ortaya çıkarabilecektir. Hastaların genellikle şehrin merkezinden uzak bölgelerde inşa edilmiş şehir hastanelerine gitmek için ulaşım maliyetlerinin artacağı öngörülmektedir. Yakın zamanda şehir hastanelerinde sunulan hizmetten memnuniyet ile ilgili bir araştırmada ulaşım, hastaların sorun yaşadıkları alanlar arasında belirtilmektedir (Gökkaya ve diğerleri, 2018: 146).

$\mathrm{Bu}$ çalışma güncel ve yapım süreci devam eden şehir hastanelerinin gazetelerde nasıl yansıdığının belirlenmesi amacıyla gerçekleştirilmiştir. Hastaneler halen açılma ve yeni kullanım sürecinde olup, yapılma aşamasında belirlenen hedeflere ulaşılıp ulaşılamayacağının zaman içinde belli olacağı söylenebilir. Gelecekte gerçekleştirilecek çalışmalarda şehir hastanelerinden alınan sağlık hizmetinden memnuniyet, hastanelerin fiziki ve teknolojik özelliklerinden memnuniyet, şehir hastanelerinin şehirlere katkısı gibi konular araştırılabilir. 


\section{KAYNAKÇA}

Acartürk, Ertuğrul ve Keskin, Sabiha, (2012) “Türkiye'de Sağl1k Sektöründe Kamu Özel Ortaklığı Modeli”, Süleyman Demirel Üniversitesi İktisadi ve İdari Bilimler Fakültesi Dergisi 17(3), s.25-51.

Cerrahoğlu, Ali, (2016) "Şehir Hastaneleri ve Birinci Basamak", The Journal of Turkish Family Physician 7(3), s.81-84.

Çınar, Naif Fıratcan., Türkoğlu, Çağdaş ve Tütünsatar, Alper, (2017) "Kamu-Özel Ortaklığı/İşbirliği Modeli ve Sağlik Hizmetlerinin Sunumunda Hizmet Memnuniyetinin Ölçülmesi: Entegre Sağlık Kampüsleri (Şehir Hastaneleri) İçin Bir Araştırma”, Süleyman Demirel Üniversitesi Sosyal Bilimler Enstitüsü Dergisi 29(4), s.215-232.

Çınarlı, İnci, (2008) Sağlık İletişimi ve Medya, 1. bs, Nobel Yayın Dağıtım, Ankara.

Ertem, Gül, Dönmez, Yelda Candan ve Oksel, Esra, (2009) "Günlük Gazetelerde Hemşirelik Haberlerin İncelenmesi” Maltepe Üniversitesi Hemşirelik Bilim ve Sanatı Dergisi 2(2), s.70-75.

Gökkaya, Dumuş, İzgüden, Dilruba ve Erdem, Ramazan, (2018) "Şehir Hastanesinde Hasta Memnuniyeti Araştırması: Isparta İli Örneği”, Vizyoner Dergisi 9(20), s.136-148.

Hürriyet Gazetesi, (2018) Hürriyet Gazetesi, Erişim Tarihi: 02.12.2018, http://www.hurriyet.com.tr/

Karahanoğulları, Yiğit, (2012) "Kamu Özel Ortaklığı Modelinin Mali Değerlendirmesi”, Ankara Üniversitesi SBF Dergisi s.67(2), 95-125.

Karasu, Koray, (2011) "Sağlık Hizmetlerinin Örgütlenmesinde Kamu-Özel Ortaklı̆̆ı", Ankara Üniversitesi SBF Dergisi 66(3), s.217-262.

Kerman, Uysal, Altan, Yakup, Aktel, Mehmet ve Eke, Erdal, (2012) "Sağlık Hizmetlerinde Kamu Özel Ortaklığı Uygulaması", Süleyman Demirel Üniversitesi İktisadi ve İdari Bilimler Fakültesi Dergisi 17(3), s.1-23.

McKee, Martin, Edwards, Nigel, \& Atun, Rifat, (2006) "Public-Private Partnerships for Hospitals", Bulletin of the World Health Organization 84(11), s.890-896.

Milliyet Gazetesi. (2018), Milliyet gazetesi, erişim tarihi: 14.12.2018, http://www.milliyet.com.tr/ Öner, M, (2010) Kayseri Entegre Sağlık Kampüsü pek çok ilki barındırıyor. https://emlakkulisi.com/kayseri-entegre-saglikkampusu-pek-cok-ilki-barindiriyor/33759

Organ, Arzu ve Tekin, Bilge, (2017) "Şehir Hastanesi Kuruluş Yeri Seçimi İçin Entropi ve Gri İlişkisel Analiz Yaklaşımı: Denizli İli Örneği”, Adnan Menderes Üniversitesi Sosyal Bilimler Enstitüsü Dergisi 4(3), s.256-278.

Özşaker, Esma, İlçe, Arzu Özcan, Dönmez, Yelda Candan ve Dıramalı, Alev, (2007) "Gazetelerde Meme Sağlı̆̆ı İle İlgili Haberlerin İncelenmesi”, Sosyal Politika Çalışmaları Dergisi 3(11), s.77-82.

Sabah Gazetesi, (2018) Sabah Gazetesi, Erişim Tarihi: 02.12.2018, https://www.sabah.com.tr/ Sadeghi, A., Barati, O., Bastani, P., Jafari, D. D. ve Etemadian, M, (2016) "Experiences of Selected Countries in the Use of Public-Private Partnership in Hospital Services Provision”, J Pak Med Assoc 66(11), s.1401-1406.

Sağlı Bakanlığı, (2012) Stratejik Plan 2013-2017, erişim tarihi: 14.12.2018, http://dosyasb.saglik.gov.tr/Eklenti/9843,saglik-bakaligi-stratejik-plan--2013-2017pdf.pdf

Sağlık Bakanlığı, (2018a) Şehir Hastaneleri ve Koordinasyon Dairesi Başkanlığı sık sorulan sorular, erişim tarihi: 14.12.2018, https://www.khgm.saglik.gov.tr/DB/37/14488_sik-sorulan-sorular

Sağlık Bakanlığı, (2018b) 2019 Yılı Bütçe Sunumu TBMM Plan Bütçe Komisyonu, erişim tarihi: 14.12.2018, https://sgb.saglik.gov.tr/Shared\%20Documents/2019\%20Y\%C4\%B11\%C4\%B1\%20B\%C3\%BCt\%C3\%A7e\%20 Sunumu.pdf

Ünal, Ali ve Köse Ünal, Aslı, (2017) "Sağlık Sektöründe Kamu Özel Ortaklığına Yönelik Sağlık Yöneticilerinin Görüşleri”, Sağlık Akademisyenleri Dergisi 4(1), s.51-56.

Zeyrek, Deniz, (1992) “Gazete Haber Başlıklarını İnceleme Denemesi”, Dilbilim Araştırmaları Dergisi 3, s.59-96. 